\title{
Thickness Dependent Magnetic Study of Fe Thin Films
}

\author{
R. Brajpuriya*, A. Vij, Ram K. Sharma \\ University of Petroleum and Energy Studies (UPES), PO Bidholi Via Premnager, Dehradun, Uttarakhand, India
}

(Received 11 March 2021; revised manuscript received 12 August 2021; published online 20 August 2021)

\begin{abstract}
In the present work, studies of the magnetic properties of Fe films of various thickness $(150,200,300$, and $400 \AA$ ) deposited on float glass substrate by electron beam (EB) deposition technique are reported. The investigation was prompted by the lack of data on evaporated Fe films in this thickness regime. For comparison, the magnetic properties of a Fe film deposited by ion beam sputtering (IBS) technique of a thickness of $300 \AA$ have also been investigated. Magnetic properties like coercivity, saturation magnetization, retentivity etc. have been obtained by analysis of $M-H$ loops recorded at room temperature, and the variation in these parameters has been correlated to the film thickness. All the films show high anisotropy with respect to spin alignment with nearly all the spins lying in the plane of the film. A systematic increase in the saturation magnetization is observed with an increase in sample thickness. The magnetic properties of the IBS film are not very different from the EB samples except for a $11 \%$ decrease in the coercivity which can be attributed to lesser roughness of the IBS film. This is reflected in the squareness ratio of nearly 1 for all the samples.
\end{abstract}

Keywords: Fe thin film, VSM, Magnetic properties, Electron beam evaporation.

\section{INTRODUCTION}

Thin films have been known to mankind for more than a hundred years. A thin film is defined as a lowdimensional material created by condensing atoms or molecules of matter. Thin films have a great impact on modern era of technology. Thin films are considered as a basis for advanced applications in various fields such as optical devices, environmental applications, telecommunication devices, energy storage devices, magnetic memory devices, decorative parts and so on [1-5]. Recent advances in the field of thin films provide an opportunity for further technological applications and allow designing new materials. Thin films also offer an important testing ground for the understanding of atomic interactions. The development of materials of specific characteristics tailored to a specific application requires a complete understanding of their microscopic interactions and their dependence on composition and preparation. Fundamentally as the thickness of the deposited material decreases to a few monolayers, quantum size effects become important, which in turn influence the magnetic, optical and electronic properties.

At present, the study of magnetic thin films is of current scientific and technological interest [6, 7]. A rapid development of magnetic storage media has been witnessed during the last decade. Each element storing magnetic information must consist of ultrafine particles in order to yield further development. As the magnetic elements continue to decrease in size and approach the ultrathin region, the magnetization of the elements is influenced by thermal fluctuations. Thus, the understanding of the critical size for the magnetic particles to keep the ferromagnetic state at room temperature is a key issue for magnetic storage. In these structures, properties such as coercivity, magnetic anisotropy, and magnetostriction can be tuned by changing the grain size [8]. When averaged over the entire volume of the film, these properties can therefore be expected to depend strongly on the volume to surface ratio, i.e., its thickness. In this regard, very few reports are available in the literature, which deals with the study of Fe thin film as a function of its layer thickness [9, 10]. The present investigation was prompted by the lack of data on evaporated Fe films in the thickness regime below $500 \AA$. The purpose of the present study is therefore to understand the changes in both the magnetic saturation and coercivity in evaporated Fe films as a function of film thickness.

\section{EXPERIMENTAL DETAILS}

Fe thin films were prepared by electron beam evaporation method on glass substrates. Ex situ cleaning of the substrate was carried out before the start of film synthesis. The pressure before and during deposition was typically below $1 \times 10^{-10}$ and $1 \times 10^{-7}$ torr, respectively. The growth rate was $0.1 \AA / \mathrm{s}$ and the thickness of Fe varied from $150 \AA$ to $400 \AA$. The growth temperature was fixed at $323 \mathrm{~K}$. Magnetic properties were measured using a vibrating sample magnetometer (VSM) with fields up to 500 Oe. The measurements were performed in one configuration, in which the magnetic field was parallel to the film plane. The measurements were not made in situ, and therefore all the films were exposed to air before measurement. Although the surface of the films was oxidized, repeated measurements on selected samples over three months indicated negligible change in the magnetic properties with time.

\section{RESULTS AND DISCUSSION}

$M-H$ loops obtained for the samples of various thicknesses, recorded at room temperature, are shown in Fig. 1. Since the saturation field for all the samples is around $50 \mathrm{Oe}, M-H$ loops have been recorded for a

\footnotetext{
*ranjeetbjp@yahoo.co.in
} 

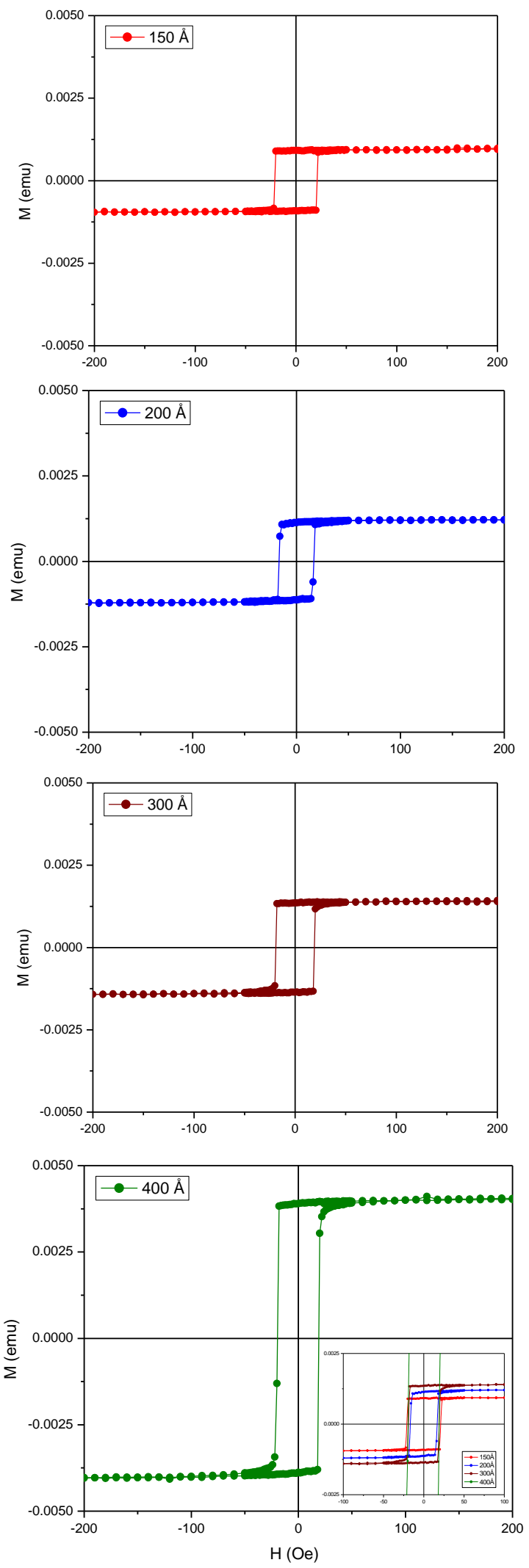

Fig. $1-M-H$ loops of Fe films as a function of thickness

range of \pm 200 Oe with a step size of 1 Oe. The magnetic parameters vs saturation magnetization $(M s)$, retentivity $(M r)$, coercivity $\left(H_{C}\right)$, squareness ratio $(M r / M s)$ obtained from hysteresis loops as a function of thickness are plotted in Fig. 2. A comparison of the quanti- ties shows that there is a systematic trend as a function of thickness in these films. When recording the $M-H$ loops, since the field was always applied parallel to the plane of the film, the square shape of the loops indicates that the magnetic moments are aligned along the plane of the film. This is confirmed by the fact that the squareness ratio, i.e., the ratio of saturation magnetization to retentivity, is close to or equal to 1 for all samples, with only a $200 \AA$ thick sample showing a slightly poorer squareness ratio of 0.92 . The reason for the in-plane alignment of spins in thin films, as is generally observed, is the large surface strains induced by the reduced symmetry. The trend of retentivity with thickness is the same as saturation magnetization.

The coercivity $\left(H_{C}\right)$ of samples is used to classify ferromagnetic materials into 'hard' and 'soft' categories. In the present samples, the coercivities are quite low and so these films can still be categorized as soft. However, bulk, pure iron is magnetically very soft with coercivities of the order of a few Oe, while in these samples it is of the order of 20 Oe. As observed before, film deposition is a non-equilibrium process, in which the surface is greatly strained. Thus, from the plot of coercivity vs. thickness given below, it can be seen that the film with the least thickness, viz., that with a thickness of $150 \AA$, has the largest coercivity. This is expected since, being very thin, this sample is expected to have more broken bonds and surface strain which 'pin' the spins, so that an easy reversal is not possible resulting in higher $H_{C}$. At $200 \AA$, there is now enough thickness for some loosening of spins which are then more easily aligned. This is also reflected in the lowest squareness factor for this sample. Again, with increasing thickness, since film deposition is achieved by a layer-by-layer method, the alignment of spins in the lower layers strongly affects the spins in the upper layers, and so the coercivity increases slightly again to level of $400 \AA$.
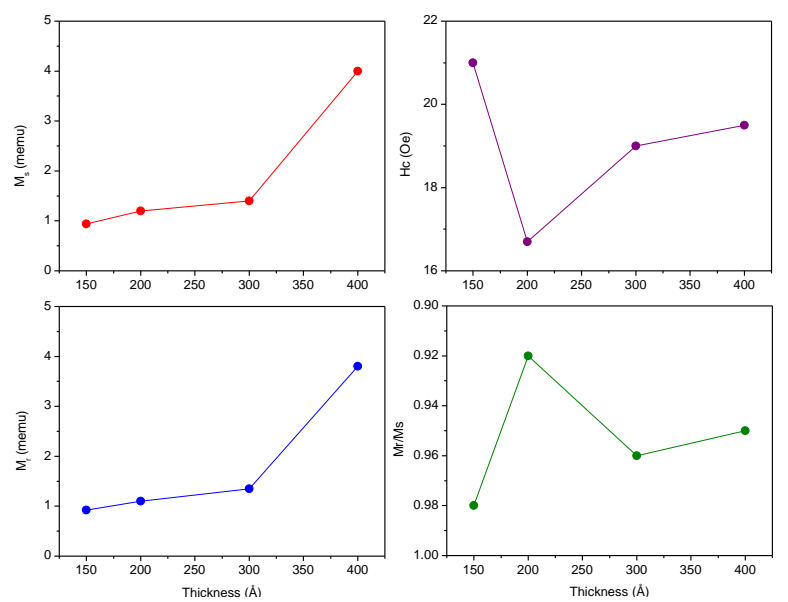

Fig. 2 - Magnetic parameters obtained from the $M-H$ loops as a function Fe film thickness

A comparison of the magnetic properties of a $300 \AA$ sample made by ion beam sputtering (IBS) technique with those made by EB of the same thickness shows that they are nearly the same, with only a slight decrease of about $11 \%$ in the coercivity of the IBS film. This may be because the EB deposited film is slightly rougher than the film obtained by IBS method. 


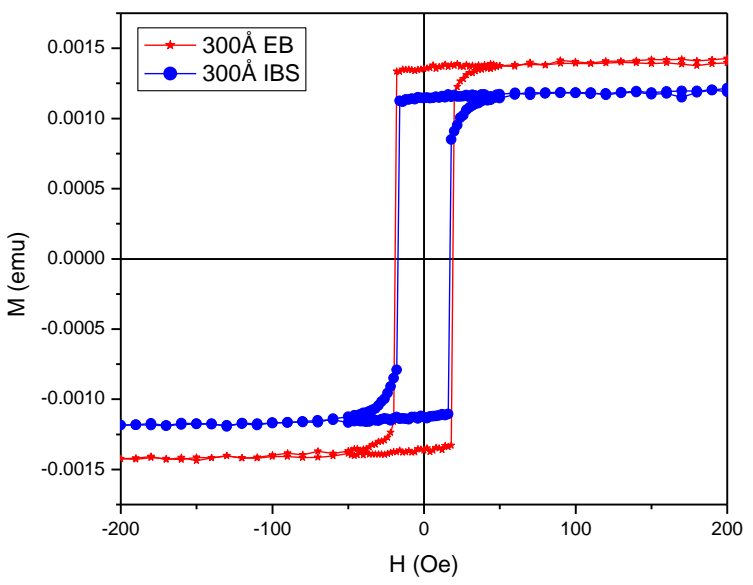

Fig. 3 - Comparison of the $M-H$ loops of Fe (300 $\AA)$ films deposited by EB and IBS

\section{CONCLUSIONS}

In this study, we investigated the thickness dependence of the magnetic state of Fe thin films. The magnetic properties of the EB evaporated Fe film (300 ̊) were compared with those of the film deposited by IBS. The magnetic properties obtained by the analysis of the $M-H$ loops were recorded, and the variation in these parameters correlated with the film thickness. All the films exhibited isotropic in-plane magnetic hysteresis loops characteristic of soft Fe films with high squareness and relatively low coercivity. Most of the samples exhibited squareness above $90 \%$. An anomalous variation in coercivity and squareness ratio was found for a sample with a film thickness of $200 \AA$. A systematic increase in the saturation magnetization was observed with increasing sample thickness. The magnetic properties of the IBS film are not very different from the EB samples except for a $11 \%$ decrease in coercivity which can be attributed to lesser roughness of the IBS film.

\section{ACKNOWLEDGEMENTS}

The author (R. B.) would like to acknowledge Prof. N. Laxmi, MLSU for providing VSM facility.

5. Y. Gao, H. Niu, C.Q. Chen, Chem. Phys. Lett. 367, 141 (2003).

6. S.Y. Chou, P.R. Krauss, L.J. Kong, J. Appl. Phys. 79, 6101 (1996).

7. M. Rührig, S. Porthun, J.C. Lodder, S. McVitie, L.J. Heyderman, A.B. Johnston, J.N. Chapman, J. Appl. Phys. 79, 2913 (1996).

8. Y.Y. Oshizawa, S. Oguma, K.Y. Amauchi, J. Appl. Phys. 64, 6044 (1988).

9. A. Vyas, S. Rajan, A. Kumar, R. Brajpuriya, Appl. Phys. A 116, 2125 (2014)

10. Low temperature noncollinear behavior in ultrathin $\mathrm{Fe} / \mathrm{Al}$ multilayer structures J. Appl. Phys. 107 No 8, 083914 (2010).

\title{
Дослідження залежних від товщини магнітних властивостей тонких плівок Fе
}

\author{
R. Brajpuriya, A. Vij, Ram K. Sharma
}

University of Petroleum and Energy Studies (UPES), PO Bidholi Via Premnager, Dehradun, Uttarakhand, India

\begin{abstract}
У роботі вивчено магнітні властивості плівок Fe різної товшини (150, 200, 300 і $400 \AA$ А), нанесених на підкладку з термополірованого скла методом електронно-променевого (ЕВ) осадження. Дослідження було спричинене відсутністю даних про нанесені випаровуванням плівки Fе у заданому діапазоні товщин. Для порівняння також було досліджено магнітні властивості плівки Fe товщиною $300 \AA$, нанесеної методом іонно-променевого напилення (IBS). Магнітні властивості, такі як коерцитивність, намагніченість насичення, залишкова намагніченість тощо, були отримані з аналізу петель $M$ - $H$ при кімнатній температурі, а варіація цих параметрів корелювала з товщиною плівки. Всі плівки демонструють високу анізотропію по відношенню до вирівнювання спінів, причому майже всі спіни лежать у площині плівки. Систематичне збільшення намагніченості насичення спостерігається із збільшенням товщини зразка. Магнітні властивості плівки IBS не сильно відрізняються від властивостей зразків ЕВ, за винятком зменшення коерцитивності на $11 \%$, яке можна пояснити меншою шорсткістю плівки IBS. Це відображаеться у коефіцієнті прямокутності, що приблизно дорівнюе 1 для всіх зразків.
\end{abstract}

Ключові слова: Тонка плівка Fe, VSM, Магнітні властивості, Електронно-променеве випаровування. 